\title{
Effects of feeding canola meal or wheat dried distillers grains with solubles as a major protein source in low- or high-crude protein diets on ruminal fermentation, omasal flow, and production in cows
}

\author{
T. Mutsvangwa, ${ }^{1}$ D. Kiran, ${ }^{2}$ and S. Abeysekara \\ Department of Animal and Poultry Science, University of Saskatchewan, Saskatoon, SK, Canada, S7N 5A8
}

\begin{abstract}
The objective of this study was to determine the effects of feeding canola meal (CM) or wheat dried distillers grains with solubles (W-DDGS) as the major source of protein in diets varying in crude protein (CP) content on ruminal fermentation, microbial protein production, omasal nutrient flow, and production performance in lactating dairy cows. Eight lactating dairy cows were used in a replicated $4 \times 4$ Latin square design with 29 -d periods (21 d of dietary adaptation and $8 \mathrm{~d}$ of measurements) and a $2 \times 2$ factorial arrangement of dietary treatments. Four cows in 1 Latin square were ruminally cannulated to allow ruminal and omasal sampling. The treatment factors were (1) source of supplemental protein (CM vs. W-DDGS) and (2) dietary CP content (15 vs. 17\%; DM basis). Diets contained $50 \%$ forage and $50 \%$ concentrate, and were fed twice daily at 0900 and $1600 \mathrm{~h}$ as total mixed rations for ad libitum intake. Dry matter intake and milk yield were unaffected by dietary treatments; however, milk yield in cows that were fed CM was numerically greater $(+1.1 \mathrm{~kg} / \mathrm{d})$ when compared with cows fed W-DDGS. Feeding CM increased milk lactose content compared with feeding W-DDGS. Milk urea nitrogen and ruminal $\mathrm{NH}_{3}-\mathrm{N}$ concentrations were greater in cows fed the high-CP compared with those fed the low-CP diet. The rumen-degradable protein supply was greater in cows fed the high-CP when compared with those fed the low-CP diet when diets contained CM, whereas rumen-degradable protein supply was lower in cows fed the high-CP when compared with those fed the low-CP diet when diets contained W-DDGS. Total $\mathrm{N}$ flow at the omasal canal was not affected by diet; however, omasal flow of $\mathrm{NH}_{3}-\mathrm{N}$ was greater in cows fed CM when compared with those fed W-DDGS. The rumen-undegradable protein supply was greater in
\end{abstract}

\footnotetext{
Received June 19, 2015.

Accepted November 2, 2015.

${ }^{1}$ Corresponding author: tim.mutsvan@usask.ca.

${ }^{2}$ Current address: Evonik (SEA) Pte. Ltd., 3 International Business Park, \#07-18 Nordic European Centre, Singapore 609927.
}

cows fed the low-CP when compared with those fed the high-CP diet when diets contained CM, whereas rumen-undegradable protein supply was lower in cows fed the low-CP when compared with those fed the high-CP diet when diets contained W-DDGS. Omasal flow of fluid-associated bacteria was greater and that of particle-associated bacteria tended to be greater in cows fed CM when compared with those fed W-DDGS; however, omasal flow of total microbial nonammonia $\mathrm{N}$ was unaffected by dietary treatment. Omasal flows of threonine and tryptophan were greater, whereas that of histidine and lysine tended to be greater in cows fed CM when compared with those fed W-DDGS. Our results show that when dairy diets are formulated to contain 15 or $17 \% \mathrm{CP}, \mathrm{CM}$ or W-DDGS can be used as the major source of protein and achieve similar levels of milk production.

Key words: dairy cow, wheat-based dried distillers grains with solubles, canola meal, nutrient supply, milk production

\section{INTRODUCTION}

Traditionally, dairy cow diets in western Canada and parts of the United States typically contain canola meal (CM) as the principal source of protein because it is readily available and is a good quality protein supplement (Hickling, 2008; Mulrooney et al., 2009). Solvent-extracted CM contains high concentrations of CP (range of 40 to $44 \%$; DM basis) and lysine (range of 4.88 to $5.56 \%$ of CP; Newkirk, 2009; Maxin et al., 2013a), thus making it well-suited for use as a protein supplement for dairy cows. Not surprisingly, numerous studies have been conducted to compare lactational performances of dairy cows fed CM as a substitute for other sources of protein, such as soybean meal (e.g., Brito and Broderick 2007; Christen et al., 2010; Broderick et al., 2015). In a meta-analysis of milk production responses to substituting $\mathrm{CM}$ for other protein supplements in dairy cow diets, Martineau et al. (2013) concluded that milk production in cows fed CM was usually greater than that observed in cows fed other protein supplements. 
Conversely, major growth of the ethanol industry in western Canada using wheat as the principal feedstock has resulted in large quantities of wheat-based dried distillers grains with solubles (W-DDGS) being available as an alternative protein supplement for dairy cows. When compared with CM, W-DDGS contains less CP $(37.2 \%)$ and is a poorer source of lysine $(2.53 \%$ of CP; Maxin et al., 2013a), suggesting that feeding W-DDGS as the major source of protein in place of CM could potentially compromise milk and milk protein yields due to a deficiency in lysine supply. To our knowledge, only one published study (Chibisa et al., 2012) has directly compared CM and W-DDGS as the major sources of supplemental protein in dairy cows fed barley-based diets that are typical of western Canada. Chibisa et al. (2012) reported that cows fed diets containing WDDGS had greater milk yields when compared with those fed CM, a response that was attributed to greater DMI with W-DDGS. A potential shortcoming of that study was that experimental diets contained nearly $19 \% \mathrm{CP}$; consequently, even if dietary lysine content was lower in diets containing W-DDGS compared with $\mathrm{CM}$, the omasal flows of lysine were similar and met requirements. From an environmental standpoint, feeding high-CP diets poses a risk due to the excretion of large amounts of $\mathrm{N}$ and it is now common to feed diets with 15 to $17 \% \mathrm{CP}$ on dairy farms in western Canada (Chibisa and Mutsvangwa, 2013).

An in situ study conducted by Maxin et al. (2013a) indicated that the ruminal $\mathrm{CP}$ degradability of $\mathrm{W}$ DDGS was higher than that of CM (53.2 vs. $47.5 \%$ ). Because of the differences in RDP content of these 2 protein supplements, feeding either as the major source of dietary protein could have differential effects on ruminal microbial protein production. In addition to the source of dietary protein, dietary $\mathrm{CP}$ content can also have major effects on RDP supply, as the amount of dietary $\mathrm{CP}$ that is degraded in the rumen increases with dietary CP content (Colmenero and Broderick, 2006a). When dietary CP content is altered in diets containing either W-DDGS or CM as the major protein sources, the effect on RDP supply might be different due to differences in RDP content between $\mathrm{CM}$ and W-DDGS. Therefore, it is important to determine how changing dietary $\mathrm{CP}$ content and RDP supply interact to alter $\mathrm{N}$ utilization and production responses in diets containing $\mathrm{CM}$ or W-DDGS as the major source of protein. For the present study, our hypothesis was that at similar dietary $\mathrm{CP}$ content differences in the RDP content between CM and W-DDGS would result in differences in ruminal $\mathrm{N}$ utilization and omasal nutrient flows. Therefore, our objective was to determine the effects of feeding CM or W-DDGS as the major source of protein in diets containing 15 or $17 \% \mathrm{CP}$ on ruminal fermentation, microbial protein production, omasal nutrient flow, and production performance in lactating dairy cows.

\section{MATERIALS AND METHODS}

\section{Animals and Experimental Design}

Eight multiparous Holstein cows $(710 \pm 60 \mathrm{~kg}$ of BW; $109 \pm 36$ DIM) were used in a replicated $4 \times 4$ Latin square design with a $2 \times 2$ factorial arrangement of treatments. Four cows in 1 Latin square were ruminally cannulated to allow ruminal and omasal sampling. The first $21 \mathrm{~d}$ of each period were used for dietary adaptation and the last $8 \mathrm{~d}$ for data and sample collection. Throughout the experiment, cows were housed individually in tiestalls at the Greenbrae Dairy Research Facility (University of Saskatchewan). Experimental cows were cared for and handled in accordance with the Canadian Council of Animal Care (1993) regulations and their use in this experiment was approved by the University of Saskatchewan Animal Care Committee (UCACS Protocol No. 20040048).

\section{Experimental Treatments and Feeding Management}

The treatment factors that were tested were the source of supplemental protein (CM vs. W-DDGS) and dietary CP content (15 vs. 17\%; DM basis). For diets with the same $\mathrm{CP}$ content, the inclusion rates of $\mathrm{CM}$ and W-DDGS were similar (Table 1). Single batches of CM and W-DDGS were used for the entire study. Within each CP level, the inclusion rates of $\mathrm{CM}$ and W-DDGS were similar by design. Because W-DDGS and $\mathrm{CM}$ differ in their $\mathrm{CP}$ contents, it was necessary to include small amounts (relative to the inclusion rates of CM and W-DDGS) of soybean meal and corn gluten meal to make diets isonitrogenous at each $\mathrm{CP}$ level. When dietary CP level was increased from 15 to $17 \%$, however, the additional $\mathrm{CP}$ came primarily from $\mathrm{CM}$ and W-DDGS and also from higher inclusion levels of soybean meal and corn gluten meal. Because we wanted the inclusion levels of CM and W-DDGS to be similar, it was not possible to maintain similar levels of inclusion for soybean meal and corn gluten meal across CP levels. Even though the inclusion levels of soybean meal and corn gluten meal were different, it should be noted that all diets contained the same supplemental sources of protein, which would provide similar profiles of AA. Experimental diets were fed twice daily at 0900 and $1600 \mathrm{~h}$ as TMR for ad libitum intake. The forage-to-concentrate ratio of the TMR was 50:50, with the forage component of the TMR being a 65:35 (DM basis) mixture of barley silage and chopped alfalfa hay, 
Table 1. Ingredient and chemical composition of experimental diets with low or high CP levels and containing canola meal (CM) or wheat-dried distillers grains with solubles (W-DDGS) as the major source of protein

\begin{tabular}{|c|c|c|c|c|}
\hline \multirow[b]{2}{*}{ Item } & \multicolumn{2}{|c|}{ Low CP } & \multicolumn{2}{|c|}{ High CP } \\
\hline & $\mathrm{CM}$ & W-DDGS & $\mathrm{CM}$ & W-DDGS \\
\hline \multicolumn{5}{|l|}{ Ingredients, \% DM } \\
\hline Barley silage & 33.3 & 33.4 & 33.1 & 32.7 \\
\hline Barley grain & 29.8 & 28.9 & 28.7 & 28.3 \\
\hline Alfalfa hay & 16.5 & 16.5 & 16.3 & 16.1 \\
\hline $\mathrm{CM}$ & 11.1 & 0.00 & 15.9 & 0.00 \\
\hline W-DDGS & 0.00 & 12.0 & 0.00 & 15.7 \\
\hline Soybean hulls & 3.11 & 3.56 & 0.44 & 0.44 \\
\hline Cottonseed hulls & 2.22 & 1.34 & 0.44 & 0.44 \\
\hline Soybean meal & 0.31 & 0.45 & 0.88 & 1.31 \\
\hline Corn gluten meal & 0.31 & 0.45 & 0.88 & 1.74 \\
\hline Molasses, dried & 0.24 & 0.24 & 0.24 & 0.24 \\
\hline Dynamate $^{1}$ & 0.17 & 0.17 & 0.17 & 0.17 \\
\hline Limestone, ground & 0.24 & 0.24 & 0.24 & 0.24 \\
\hline Sodium bicarbonate & 0.97 & 0.97 & 0.97 & 0.96 \\
\hline Dairy premix ${ }^{2}$ & 1.76 & 1.76 & 1.76 & 1.76 \\
\hline \multicolumn{5}{|l|}{ Chemical composition } \\
\hline DM, $\%$ & 55.7 & 55.6 & 55.7 & 55.9 \\
\hline $\mathrm{OM}, \%$ of $\mathrm{DM}$ & 91.6 & 91.8 & 91.6 & 91.6 \\
\hline $\mathrm{CP}, \%$ of DM & 15.3 & 15.2 & 16.9 & 17.1 \\
\hline NDF, $\%$ of DM & 32.5 & 32.1 & 32.3 & 31.8 \\
\hline $\mathrm{ADF}, \%$ of $\mathrm{DM}$ & 20.1 & 17.8 & 18.7 & 17.4 \\
\hline Ether extract, \% of DM & 2.85 & 3.68 & 3.15 & 3.98 \\
\hline $\mathrm{NFC}^{3} \%$ of DM & 38.2 & 38.3 & 37.9 & 38.1 \\
\hline $\mathrm{NE}_{\mathrm{L}},{ }^{3} \mathrm{Mcal} / \mathrm{kg}$ of DM & 1.66 & 1.65 & 1.69 & 1.64 \\
\hline
\end{tabular}

${ }^{1}$ Contained $18 \% \mathrm{~K}, 11 \% \mathrm{Mg}$, and $22 \% \mathrm{~S}$.

${ }^{2}$ Contained (per kg of premix; DM basis): 330,000 IU of vitamin A, 60,000 IU of vitamin D, 1,000 IU of vitamin E, $16 \% \mathrm{Ca}, 8.5 \% \mathrm{P}, 6.3 \% \mathrm{Na}, 4.5 \% \mathrm{Mg}, 2,100 \mathrm{mg}$ of $\mathrm{Zn}, 1,500 \mathrm{mg}$ of $\mathrm{Mn}, 535 \mathrm{mg}$ of Cu, $12 \mathrm{mg}$ of Se, and 45 mg of I.

${ }^{3}$ Calculated from CPM Dairy Ration Analyzer v3.0.0 (University of Pennsylvania, Kennett Square, PA).

respectively. Dietary ingredient and chemical compositions are presented in Table 1.

\section{Data and Sample Collection}

During the 8-d data collection period (d 21-29), individual cow feed intake was recorded daily. Samples of TMR and orts were collected daily and stored at $-20^{\circ} \mathrm{C}$. Experimental cows were milked 3 times daily, at 0500, 1300, and $1900 \mathrm{~h}$, and milk weights were recorded. Milk samples were collected daily on 3 consecutive days (d 21,22 , and 23) from all 3 milkings into vials containing a preservative (2-bromo-2-nitropropane-1-2-diol). Samples were then pooled proportionally based on milk yield on a daily basis. Pooled milk samples were submitted to the CanWest DHI Milk Testing Laboratory (Edmonton, AB, Canada) for protein, fat, lactose, and MUN analysis using a near infrared analyzer (Foss System 4000, Foss Electric, Hillerod, Denmark) according to AOAC (1990).

On d 21 of each experimental period, 1,000 $\mathrm{mL}$ of ruminal contents were collected by manually taking 250 $\mathrm{mL}$ of ruminal contents from the cranial ventral, caudal ventral, central, and cranial dorsal rumen through the cannula just before the morning feeding at $0900 \mathrm{~h}$, and then at 3 -h intervals over a 24 -h feeding cycle. After each sampling, ruminal contents were squeezed through 4 layers of cheesecloth. Ruminal fluid $\mathrm{pH}$ was then measured immediately using a Model 265A portable $\mathrm{pH}$ meter (Orion Research Inc., Beverly, MA). Two 5-mL aliquots of strained ruminal fluid were mixed with $1 \mathrm{~mL}$ of metaphosphoric acid (25\% wt/vol) and $1 \mathrm{~mL}$ of $1 \%$ $\mathrm{H}_{2} \mathrm{SO}_{4}$ and stored at $-20^{\circ} \mathrm{C}$ for later determination of ruminal VFA and $\mathrm{NH}_{3}-\mathrm{N}$ concentrations, respectively.

To quantify omasal digesta flow, indigestible NDF (iNDF; Reynal et al., 2005), $\mathrm{YbCl}_{3}$ (Siddons et al., 1985), and Cr-EDTA (Udén et al., 1980) were used as digesta markers for the large particle $(\mathbf{L P})$, small particle (SP), and fluid phases $(\mathbf{F P})$, respectively. To quantify ruminal microbial protein production, ${ }^{15} \mathrm{~N}$ [infused as $\left[{ }^{15} \mathrm{NH}_{4}\right]_{2} \mathrm{SO}_{4} ; 10$ atom percent excess (APE) ${ }^{15} \mathrm{~N}$; Cambridge Isotope Laboratories, Andover, MA] was used as a microbial marker (Reynal et al., 2005). Briefly, just before marker infusions into the rumen were initiated on d 22, samples of whole ruminal contents and whole-omasal digesta were taken from each cow to determine background concentrations of $\mathrm{Cr}$, $\mathrm{Yb}$, and ${ }^{15} \mathrm{~N}$ natural abundance. At the beginning of 
the infusions, priming doses equal to one-half of the daily dose of $\mathrm{Yb}, \mathrm{Cr}$, and ${ }^{15} \mathrm{~N}$ were administered via the ruminal cannula. Thereafter, between d 22 and 28, marker solutions prepared in distilled water and containing $\mathrm{Yb}(2.2 \mathrm{~g} / \mathrm{d}), \mathrm{Cr}(2.7 \mathrm{~g} / \mathrm{d})$, and ${ }^{15} \mathrm{~N}(182$ $\mathrm{mg} / \mathrm{d}$ ) were then continuously infused into the rumen at a constant rate of $1 \mathrm{~L} / \mathrm{d}$. The omasal sampling technique as described by Huhtanen et al. (1997) was used to collect omasal digesta. Sampling of omasal digesta was conducted at 6 -h intervals at $0900,1500,2100$, and $0300 \mathrm{~h}$ (d 26-27), and at 1200, 1800, 2400, and $0600 \mathrm{~h}$ (d 27-28) to represent the 24-h feeding cycle. At each sampling, $500 \mathrm{~mL}$ of omasal digesta was taken. After careful mixing to ensure representative sampling, each 500-mL omasal digesta sample was divided into subsamples of 200 and $300 \mathrm{~mL}$. The $300-\mathrm{mL}$ subsamples were pooled for each cow in each period to yield a 3.6L composite that was kept frozen at $-20^{\circ} \mathrm{C}$ for later analysis. The $200-\mathrm{mL}$ subsamples were placed in an ice bath following collection and pooled over 2 sampling times to yield a 400-mL composite sample; this was used for the isolation of particle-associated (PAB) and fluid-associated bacteria (FAB) using filtration and differential centrifugation using procedures described by Brito et al. (2009). After isolation, the PAB and FAB pellets were stored at $-20^{\circ} \mathrm{C}$.

\section{Sample Analyses}

At the end of the trial, frozen TMR and orts samples were thawed overnight at room temperature and analyzed for DM by drying in an oven at $60^{\circ} \mathrm{C}$ for $48 \mathrm{~h}$ (AOAC, 1990). Dried TMR and orts samples were ground through a 1-mm screen using a Christy-Norris mill (Christy and Norris Ltd., Chelmsford, England) and then pooled per cow for each experimental period. Pooled samples were analyzed for DM (AOAC, 1990; method 930.15 ), OM by ashing at $550^{\circ} \mathrm{C}$ for at least 8 h (AOAC, 1990; method 942.05), CP using the macroKjeldahl procedure (AOAC, 1990; method 976.05), ether extract (AOAC, 1990; method 920.39), and ADF and NDF (Van Soest et al., 1991). Heat-stable $\alpha$-amylase and sodium sulfite were used for NDF determination.

Frozen ruminal fluid samples for VFA analysis were thawed at room temperature, centrifuged at 18,000 $\times$ $g$ at $5^{\circ} \mathrm{C}$ for $15 \mathrm{~min}$, and then filtered through a 0.45 $\mu \mathrm{m}$ membrane before ruminal VFA were separated and quantified by GC as described by Erwin et al. (1961). Frozen ruminal fluid samples for $\mathrm{NH}_{3}-\mathrm{N}$ determination were thawed, centrifuged for $10 \mathrm{~min}$ at $18,000 \times \mathrm{g}$ at $5^{\circ} \mathrm{C}$ to obtain a clear supernatant, and then analyzed using a phenol-hypochlorite assay (Broderick and Kang, 1980).
The composite omasal digesta samples $(3.6 \mathrm{~L})$ were thawed at room temperature and then separated into LP, SP, and FP omasal digesta phases as described by Reynal et al. (2005). Samples of LP, SP, and FP were then freeze-dried and ground through a 1-mm screen using a Christy-Norris mill. The concentrations of $\mathrm{Cr}$ and $\mathrm{Yb}$ in $\mathrm{LP}, \mathrm{SP}$, and $\mathrm{FP}$ were determined by atomic absorption spectrophotometry and atomic emission spectroscopy, respectively, after sample digestion by the method described by Vicente et al. (2004). Concentrations of iNDF in TMR, LP, and SP were determined using 12-d ruminal in situ incubations (Reynal et al., 2005). The concentrations of $\mathrm{Cr}, \mathrm{Yb}$, and iNDF in the $\mathrm{LP}$ and $\mathrm{SP}$ and of $\mathrm{Cr}$ and $\mathrm{Yb}$ in $\mathrm{FP}$ were then used to physically recombine DM from the freeze-dried LP, $\mathrm{SP}$, and FP in the correct proportions to reconstitute the omasal true digesta (OTD) using the triple-marker method (France and Siddons, 1986). Reconstituted OTD samples were analyzed for OM, CP, ether extract, ash, NDF, ADF, and starch as described above. For $\mathrm{NH}_{3}-\mathrm{N}$ analysis, OTD samples were prepared using 10 $\mathrm{mL}$ of $\mathrm{pH} 2.2 \mathrm{Na-citrate}$ buffer as described by Reynal et al. (2005), and $\mathrm{NH}_{3}-\mathrm{N}$ determination was conducted as described above. Enrichment of ${ }^{15} \mathrm{~N}$ in NAN of OTD samples was determined by combustion to $\mathrm{N}_{2}$ gas in an elemental analyzer and continuous flow isotope ratiomass spectrometry. The ${ }^{15} \mathrm{~N}$ natural abundance samples were freeze-dried and ground through a 1-mm screen (Christy-Norris Ltd.) before being pulverized with a ball mill for NAN and ${ }^{15} \mathrm{~N}$ analyses. The FAB and PAB pellets were freeze-dried and then ground with a mortar and pestle, after which composite samples of FAB and PAB were prepared for each cow per period by combining equal amounts (DM basis) from each sampling time.

For AA analysis, TMR and OTD samples were prepared by acid hydrolysis (AOAC International, 1995; method 994.12) to liberate individual AA from proteins. Briefly, approximately $100 \mathrm{mg}$ of TMR or OTD sample was weighed and then hydrolyzed under reflux in $6 \mathrm{M} \mathrm{HCl}$ at $110^{\circ} \mathrm{C}$ for $24 \mathrm{~h}$. Hydrolyzed samples were then neutralized with $25 \%$ (wt/vol) $\mathrm{NaOH}$ and cooled to room temperature, and then the neutralized samples were then diluted to $50 \mathrm{~mL}$ total volume using sodium citrate buffer ( $\mathrm{pH} 2.2)$. The separation and quantification of individual AA in hydrolyzed samples were performed using HPLC (Shimadzu, Columbia, MD). For the determination of cysteine and methionine in TMR and OTD samples, performic acid oxidation was performed before acid hydrolysis to oxidize cysteine and methionine to cysteic acid and methionine sulfone, respectively (AOAC International, 1995; method 994.12). Tryptophan was determined after hydrolysis of $100 \mathrm{mg}$ 
of sample with $5 \mathrm{M} \mathrm{NaOH}$ at $120^{\circ} \mathrm{C}$ for $16 \mathrm{~h}$ using the method of Hugli and Moore (1972).

\section{Calculations and Statistical Analysis}

Calculations of bacterial $\mathrm{N}$ yield using ${ }^{15} \mathrm{~N}$ as a microbial marker were conducted as described by Reynal et al. (2005). Briefly, the ${ }^{15} \mathrm{~N}$ enrichment (APE) in OTD, and $\mathrm{FAB}$ and $\mathrm{PAB}$ bacterial samples were calculated as ${ }^{15} \mathrm{~N}$-APE $={ }^{15} \mathrm{~N}$-atom $\%$ in sample $-{ }^{15} \mathrm{~N}$-atom $\%$ in background sample. Flows of FAB and PAB at the omasal canal were calculated as FP NAN flow $\times(\mathrm{FP}$ $\left.{ }^{15} \mathrm{~N}-\mathrm{APE} / \mathrm{FAB}{ }^{15} \mathrm{~N}-\mathrm{APE}\right)$ and PF NAN flow $\times(\mathrm{PF}$ $\left.{ }^{15} \mathrm{~N}-\mathrm{APE} / \mathrm{PAB}{ }^{15} \mathrm{~N}-\mathrm{APE}\right)$, respectively. Total bacterial NAN flow was calculated as FAB NAN flow plus PAB NAN flow. The NAN content of OTD samples was calculated as total $\mathrm{N}$ minus ammonia $\mathrm{N}$. Omasal flows of other nutrients were calculated by multiplying DM flow by their concentration in OTD. Apparent ruminal digestion of nutrients was calculated as nutrient intake minus omasal flow of nutrient. Similarly, the flows of nonammonia, nonmicrobial N (NANMN), RUP, and RDP at the omasal canal were calculated as described by Reynal et al. (2005) as follows: NANMN flow = total NAN flow - microbial NAN flow; RUP flow = total CP flow - microbial CP flow; and RDP supply = total CP intake - RUP flow.

All data on ruminal fermentation parameters, nutrient digestibilities, and omasal flow were analyzed as a $4 \times 4$ Latin square using the MIXED procedure of SAS (SAS Institute, 2004). Production data for the 8 cows were analyzed using the MIXED procedure of SAS (SAS Institute, 2004) for a replicated $4 \times 4$ Latin square design. The models included the following independent variables: cow, period, source of protein (CM vs. W-DDGS), dietary CP content (15 vs. 17\%), and the source of protein $\times$ dietary $\mathrm{CP}$ content interaction. Period and dietary treatment were considered as fixed, whereas cow was considered as random. For dependent variables that had repeated measurements, the repeated measures option within the MIXED procedure of SAS Institute (2004) was used. Treatment differences were considered significant when $P \leq 0.05$ and tendencies when $0.05<P \leq 0.10$.

\section{RESULTS}

The diets were originally formulated to contain 15 and $17 \% \mathrm{CP}$ (DM basis) for the low- and high-CP diets, respectively, and chemical analysis showed only marginal deviations $(+0.2$ to $+0.3 \%$ units and -0.1 to $+0.1 \%$ units for the low- and high-CP diets, respectively) from the intended dietary $\mathrm{CP}$ contents (Table 1). Diets containing W-DDGS had greater contents of ether extract when compared with those containing $\mathrm{CM}$, which reflects the greater content of ether extract in W-DDGS (5.6 vs. 3.6\%; Maxin et al., 2013a).

Interactions between dietary $\mathrm{CP}$ content and source of dietary $\mathrm{CP}$ were not detected for production variables and ruminal fermentation characteristics (Tables 2 and 3 ). Dry matter intake and milk yield were unaffected by dietary treatments (Table 2). Feeding CM increased $(P<0.01)$ milk lactose content compared with feeding W-DDGS. As expected, MUN was higher $(P<0.01)$ in cows fed the high-CP compared with those fed the low-CP diet.

No differences $(P>0.05)$ were noted among dietary treatments for ruminal $\mathrm{pH}$ (Table 3). As expected, ruminal $\mathrm{NH}_{3}-\mathrm{N}$ concentration was greater $(P=0.05)$ in cows fed the high-CP when compared with those fed the low-CP diet. Ruminal VFA concentrations were largely unaffected by dietary treatment (Table 3), ex-

Table 2. Dry matter intake, milk yield, and milk composition in dairy cows fed diets with low or high CP and containing canola meal (CM) or wheat-dried distillers grains with solubles (W-DDGS) as the major source of protein ${ }^{1}$

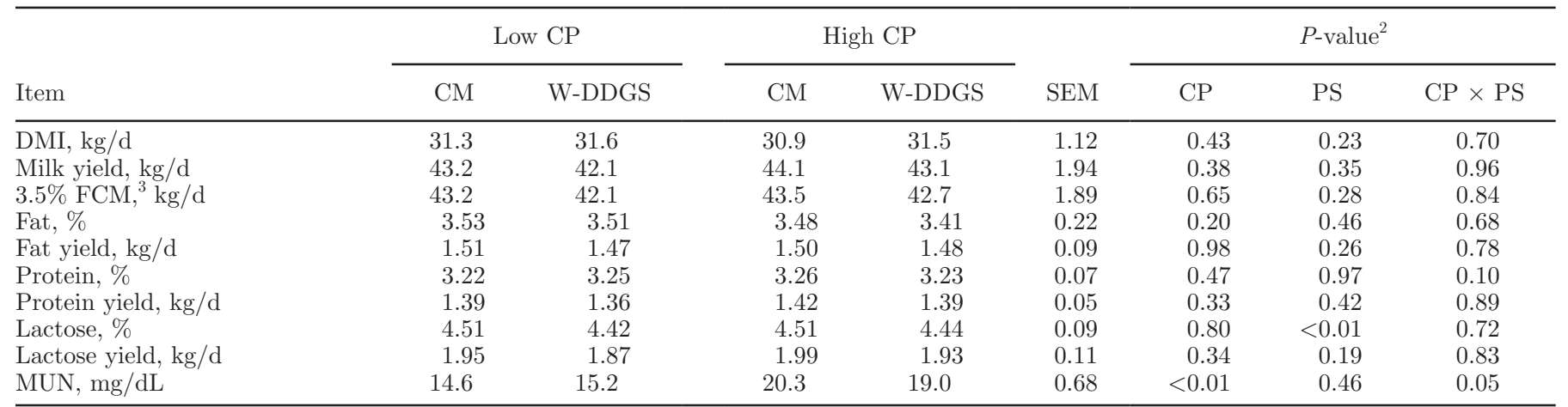

${ }^{1}$ Values are least squares means obtained from all 8 cows used in the 2 Latin squares.

${ }^{2} \mathrm{CP}=$ dietary crude protein level (low vs. high $\left.\mathrm{CP}\right) ; \mathrm{PS}=$ source of protein (CM vs. W-DDGS); and CP $\times$ PS $=$ interaction.

${ }^{3}$ Calculated as $(0.434 \times \mathrm{kg}$ of milk $)+(16.216 \times \mathrm{kg}$ of milk fat $)$. 
Table 3. Ruminal fermentation characteristics in dairy cows fed diets with low or high CP and containing canola meal (CM) or wheat-dried distillers grains with solubles (W-DDGS) as the major source of protein ${ }^{1,2}$

\begin{tabular}{|c|c|c|c|c|c|c|c|c|}
\hline \multirow[b]{2}{*}{ Item } & \multicolumn{2}{|c|}{ Low CP } & \multicolumn{2}{|c|}{ High CP } & \multirow[b]{2}{*}{ SEM } & \multicolumn{3}{|c|}{$P$-value ${ }^{3}$} \\
\hline & $\mathrm{CM}$ & W-DDGS & $\mathrm{CM}$ & W-DDGS & & $\mathrm{CP}$ & PS & $\mathrm{CP} \times \mathrm{PS}$ \\
\hline Ruminal $\mathrm{NH}_{3}-\mathrm{N}, \mathrm{mg} / \mathrm{dL}$ & 11.4 & 11.4 & 13.9 & 12.8 & 0.86 & 0.05 & 0.54 & 0.53 \\
\hline \multicolumn{9}{|l|}{ VFA concentrations, $\mathrm{m} M$} \\
\hline Acetate & 74.9 & 71.6 & 74.2 & 72.0 & 1.61 & 0.94 & 0.10 & 0.72 \\
\hline Propionate & 32.5 & 29.0 & 27.5 & 28.6 & 3.74 & 0.48 & 0.76 & 0.55 \\
\hline Valerate & 2.21 & 2.29 & 2.20 & 2.49 & 0.11 & 0.37 & 0.11 & 0.34 \\
\hline Isovalerate & 1.60 & 1.54 & 1.89 & 1.56 & 0.12 & 0.20 & 0.11 & 0.25 \\
\hline Total VFA & 125.8 & 118.0 & 120.2 & 120.6 & 4.13 & 0.72 & 0.39 & 0.34 \\
\hline
\end{tabular}

${ }^{1}$ Values are least squares means obtained from 4 ruminally cannulated cows in 1 Latin square.

${ }^{2}$ Values are means across the feeding times of $0,3,6,9,12,15,18$, and $21 \mathrm{~h}$ after a.m. feeding.

${ }^{3} \mathrm{CP}=$ dietary crude protein level (low vs. high CP); PS = source of protein (CM vs. W-DDGS); and CP $\times$ PS $=$ interaction.

cept that feeding the high-CP diet increased $(P=0.02)$ isobutyrate concentration when compared with feeding the low-CP diet, whereas feeding W-DDGS showed a tendency $(P=0.06)$ for a decrease in the molar concentration of isobutyrate when compared with feeding CM.

For the 4 ruminally cannulated cows used for omasal sampling, DMI were unaffected by diet (Table 4). When expressed in absolute amounts or as a proportion of DMI, DM that was apparently digested in the rumen was greater in cows fed the high-CP compared with those fed the low-CP diet, with the difference in
DM apparently digested in the rumen being greater in cows fed W-DDGS as compared with those fed CM (interaction; $P=0.02$ ). When expressed as absolute amounts or as a proportion of OM intake, OM that was apparently or truly digested in the rumen was greater in cows fed the high-CP when compared with those fed the low-CP diet when diets contained CM, whereas OM that was apparently or truly digested in the rumen was lower in cows fed the high-CP when compared with those fed the low-CP diet when diets contained W-DDGS (interaction, $P<0.01$; Table 4).

Table 4. Ruminal digestion and omasal flows of nutrients in dairy cows fed diets with low or high $\mathrm{CP}$ and containing canola meal (CM) or wheat-dried distillers grains with solubles (W-DDGS) as the major source of protein ${ }^{1}$

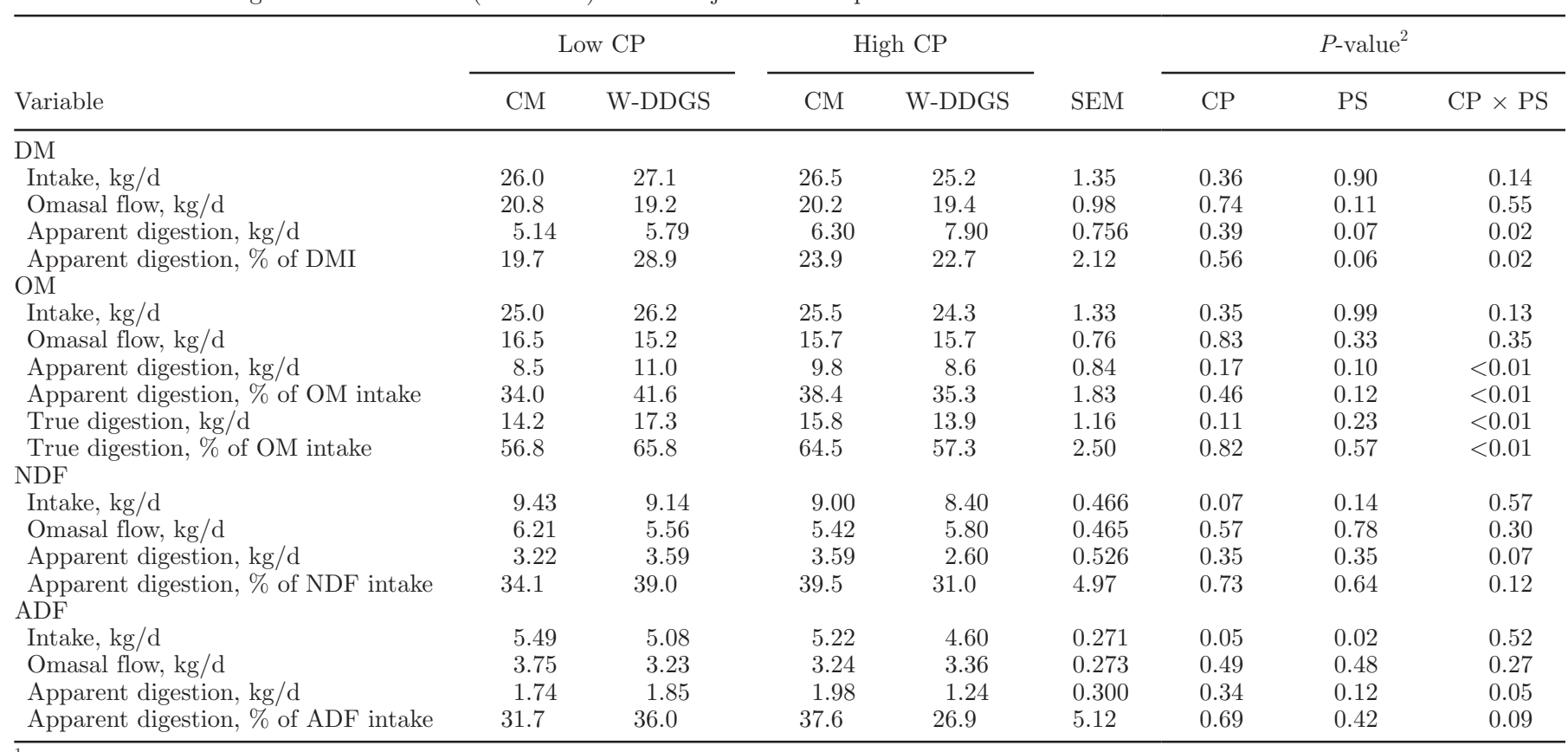

${ }^{1}$ Values are least squares means obtained from 4 ruminally cannulated cows in 1 Latin square.

${ }^{2} \mathrm{CP}=$ dietary crude protein level (low vs. high $\left.\mathrm{CP}\right)$; PS = source of protein (CM vs. W-DDGS); and CP $\times$ PS $=$ interaction. 
As expected, $\mathrm{N}$ intake was greater $(P=0.03)$ in cows fed the high-CP when compared with those fed the low$\mathrm{CP}$ diet (Table 5). When expressed as grams per day, $\mathrm{N}$ that was apparently digested in the rumen tended $(P=$ $0.07)$ to be greater in cows fed $\mathrm{CM}$ when compared with those fed W-DDGS, and it also tended to be greater $(P$ $=0.09$ ) in cows fed the low-CP when compared with those fed the high-CP diet. However, $\mathrm{N}$ that was truly digested in the rumen was not affected by dietary treatment. When expressed in absolute amounts (tendency for an interaction; $P=0.08$ ) or as a proportion of DMI (interaction, $P=0.04$ ), RDP supply was greater in cows fed the high-CP when compared with those fed the low-CP diet when diets contained $\mathrm{CM}$, whereas RDP supply was lower in cows fed the high-CP when compared with those fed the low-CP diet when diets contained W-DDGS (Table 5). Total N flow at the omasal canal was not affected by diet; however, omasal flow of $\mathrm{NH}_{3}-\mathrm{N}$ was greater $(P=0.03)$ in cows fed $\mathrm{CM}$ when compared with those fed W-DDGS. When expressed in absolute amounts (tendency for an interaction, $P$ $=0.06$ ) or as a proportion of DMI (interaction, $P=$ 0.05), RUP supply was greater in cows fed the low-CP when compared with those fed the high-CP diet when diets contained CM, whereas RUP supply was lower in cows fed the low-CP when compared with those fed the high-CP diet when diets contained W-DDGS (Table 5). Omasal flow of FAB was greater $(P \leq 0.01)$ and that of PAB tended to be greater $(P=0.10)$ in cows fed CM when compared with those fed W-DDGS; however, omasal flow of total bacterial NAN was unaffected by dietary treatment.

Interactions between dietary $\mathrm{CP}$ content and source of dietary $\mathrm{CP}$ were not detected for omasal flow of AA (Table 6). Omasal flows of total EAA, total nonessential AA, and total AA did not differ $(P>0.05)$ among diets (Table 6). Omasal flows of threonine $(P=0.03)$, tryptophan $(P<0.01)$, alanine $(P=0.05)$, asparagine $(P=0.04)$, and glycine $(P<0.01)$ were greater and that of histidine $(P=0.06)$ and lysine $(P=0.08)$ tended to be greater in cows fed $\mathrm{CM}$ when compared with those fed W-DDGS (Table 6). Dietary CP level largely had no effects on omasal AA flows, except that omasal flow of cysteine was greater $(P=0.04)$ and that of glutamate tended to be greater $(P=0.06)$ in cows fed the high-CP when compared with those fed the low-CP diet.

\section{DISCUSSION}

Results from our study showed that feeding CM or W-DDGS as the major source of supplemental protein had no effect on DMI, which is consistent with findings from a previous study that directly compared
CM and W-DDGS as protein sources (Maxin et al., 2013b). However, contrary to the present study, previous studies that involved feeding graded levels of up to $20 \% \mathrm{~W}$-DDGS with W-DDGS completely replacing CM (Chibisa et al., 2012) or CM plus corn-DDGS (Abdelqader and Oba, 2012) reported that cows fed W-DDGS had greater DMI when compared with those fed CM. The reasons for the discrepant effects of WDDGS on DMI are unclear, but could reflect that the studies conducted by Abdelqader and Oba (2012) and Chibisa et al. (2012) involved feeding graded levels of W-DDGS and inclusion levels of W-DDGS up to $20 \%$, compared with 10 to $15 \%$ in the present study. Also, W-DDGS replaced both CM and corn-DDGS in the study conducted by Abdelqader and Oba (2012); thus, their study was not a direct comparison of W-DDGS and CM as protein sources. The source of supplemental protein had no effects on milk production and composition, supporting previous findings (Maxin et al., 2013b); however, Chibisa et al. (2012) reported a linear increase in milk production when graded levels of W-DDGS replaced CM, which was attributed to a corresponding increase in DMI. Although milk production was not statistically different when CM or W-DDGS were fed as the major protein sources in the present study, it is interesting that cows fed CM produced numerically more milk $(+1.1 \mathrm{~kg} / \mathrm{d})$ when compared with those fed W-DDGS. It is plausible that the lack of statistical difference in milk yield when CM or W-DDGS were fed could be partly attributed to the rather low number of animals $(\mathrm{n}=8)$ that were used in the present study. In a comprehensive meta-analysis of up to 49 published studies that investigated the effects of the substitution of various protein sources with CM, Martineau et al. (2013) concluded that milk production responded positively $(+0.73 \mathrm{~kg} / \mathrm{d})$ when CM was substituted for other protein sources in dairy cow diets and that the response was larger when CM was substituted for protein sources such as distillers products.

In support of the present findings, no major differences in milk composition or milk component yields have been previously reported when CM and W-DDGS are fed as the major sources of supplemental protein (Chibisa et al., 2012; Maxin et al., 2013b). The only difference in milk composition that we observed in response to the source of supplemental protein was that cows fed CM had a greater milk lactose content when compared with those fed W-DDGS, which contradicts the observations of Abdelqader and Oba (2012), who reported that milk lactose content tended to be greater with W-DDGS as compared with CM. The mechanisms that are involved in changing milk lactose content when CM or W-DDGS are fed are unclear. Maxin et al. (2013b) observed that the whole-body rate of ap- 
pearance of glucose (as measured by isotopic dilution using labeled glucose infusions) was similar in cows fed CM or W-DDGS as the major protein source, so it is unclear why cows fed CM exhibited greater milk lactose contents when compared with those fed W-DDGS in the present study. We did not measure whole-body rate of appearance of glucose or blood glucose concentrations in the present study, so we cannot postulate if glucose availability was different due to protein source.

Our results showed that dietary $\mathrm{CP}$ content had no major effects on animal performance. Because feeding lower-CP diets is beneficial in reducing feed costs and improving environmental stewardship (Colmenero and Broderick, 2006a; Hristov et al., 2011), it is an approach that can be easily adopted on-farm if no detrimental effects on milk production are apparent, as demonstrated in the present study. However, perusal of the literature indicates that animal responses to feeding diets varying in $\mathrm{CP}$ content have been equivocal, although direct comparisons among studies are somewhat complicated due to variations in dietary $\mathrm{CP}$ contents that were tested. Other studies (Cabrita et al., 2011; Chibisa and Mutsvangwa, 2013) have reported positive effects of increasing dietary CP content on production performance (i.e., higher DMI and milk yield) of dairy cows. Previous work in our laboratory (Chibisa and

Table 5. Intake, digestibility, and omasal flow of $\mathrm{N}$ constituents in dairy cows fed diets with low or high $\mathrm{CP}$ and containing canola meal (CM) or wheat-dried distillers grains with solubles (W-DDGS) as the major source of protein ${ }^{1}$

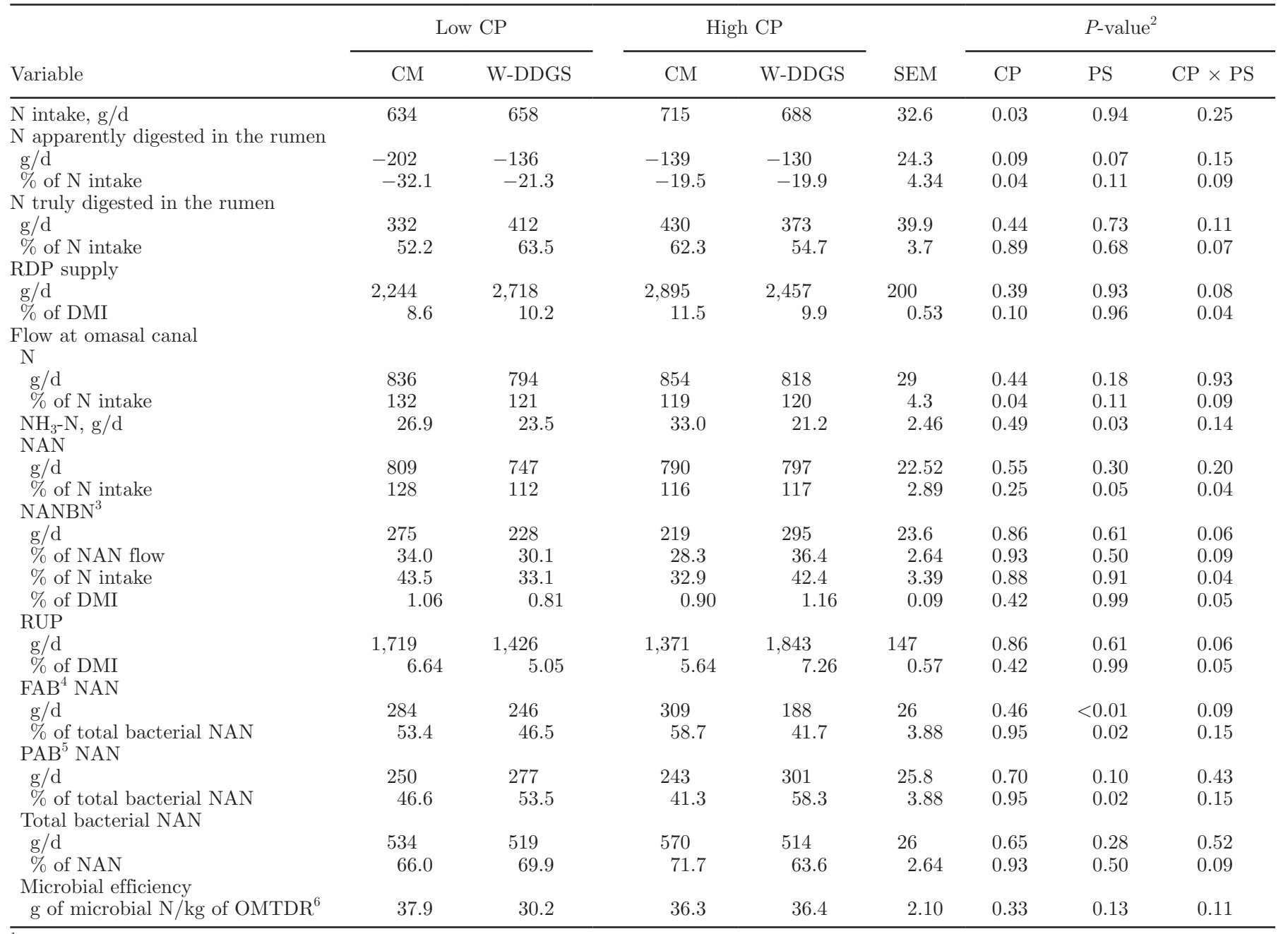

${ }^{1}$ Values are least squares means obtained from 4 ruminally cannulated cows in 1 Latin square.

${ }^{2} \mathrm{CP}=$ dietary crude protein level (low vs. high $\mathrm{CP}$ ); PS = source of protein (CM vs. W-DDGS); and CP $\times$ PS $=$ interaction.

${ }^{3} \mathrm{NANBN}=$ non- $\mathrm{NH}_{3}$ nonbacterial $\mathrm{N}$

${ }^{4} \mathrm{FAB}=$ fluid-associated bacteria.

${ }^{5} \mathrm{PAB}=$ particle-associated bacteria.

${ }^{6} \mathrm{OMTDR}=\mathrm{OM}$ truly digested in the rumen. 
Mutsvangwa, 2013) showed that when cows were fed dietary CP contents (15.2 vs. $17.3 \%$ ) similar to those in the current study, cows that were fed the lower-CP diet produced $3 \mathrm{~kg} / \mathrm{d}$ less milk when compared with cows fed the higher-CP diet. This response was primarily attributed to a greater MP supply in cows fed the higher-CP diet. In the present study, dietary $\mathrm{CP}$ content did not influence intestinal MP supply and that could partly explain why milk production was unaltered by dietary CP content. A deficiency in RDP supply when dietary $\mathrm{CP}$ content is low can also limit ruminal fiber digestion, which, consequently, can result in decreased DMI and milk yield (Firkins et al., 1986; Allen, 2000). In the present study, dietary $\mathrm{CP}$ content had no influence on any of these factors (i.e., RDP supply, ruminal fiber digestion, and DMI), which might explain why milk yields were similar across dietary CP contents. Not surprisingly, increasing dietary $\mathrm{CP}$ content in the present study elevated MUN content as has been reported elsewhere (Colmenero and Broderick, 2006b; Lee et al., 2011; Chibisa and Mutsvangwa, 2013), and this response can be attributed to the greater ruminal $\mathrm{NH}_{3}-\mathrm{N}$ concentrations that are typically observed when dietary $\mathrm{CP}$ content is increased.

Interestingly, the amounts of $\mathrm{OM}$ and $\mathrm{ADF}$ that were apparently or truly digested in the rumen was greater and that of NDF tended to be greater in cows fed the high-CP when compared with those fed the low-CP diet when diets contained CM, whereas OM that was apparently or truly digested in the rumen was lower in cows fed the high-CP when compared with those fed the low-CP diet when diets contained W-DDGS. The reasons for this interaction are unclear; however, it is interesting to note that RDP supply followed similar trends, which might suggest that differences in RDP supply could partly explain the observed differences in ruminal $\mathrm{OM}$ and fiber digestion. Ruminal $\mathrm{NH}_{3}-\mathrm{N}$ concentrations were not influenced by dietary treatment; however, it should be noted that although ruminal $\mathrm{NH}_{3^{-}}$ $\mathrm{N}$ is the major source of $\mathrm{N}$ for microbial growth (Brito et al., 2007), there is clear evidence that supplying RDP as preformed AA and peptides can stimulate microbial

Table 6. Omasal flow of amino acids ( $\mathrm{g} / \mathrm{d})$ in dairy cows fed diets with low or high $\mathrm{CP}$ and containing canola meal (CM) or wheat-dried distillers grains with solubles (W-DDGS) as the major source of protein $^{1}$

\begin{tabular}{|c|c|c|c|c|c|c|c|c|}
\hline Variable & \multicolumn{2}{|c|}{ Low CP } & \multicolumn{2}{|c|}{ High CP } & SEM & \multicolumn{3}{|c|}{$P$-value ${ }^{2}$} \\
\hline \multicolumn{9}{|l|}{ EAA } \\
\hline Histidine & 187 & 179 & 197 & 151 & 12.3 & 0.49 & 0.06 & 0.17 \\
\hline Isoleucine & 180 & 178 & 190 & 182 & 9.06 & 0.26 & 0.40 & 0.66 \\
\hline Leucine & 312 & 305 & 326 & 326 & 10.7 & 0.14 & 0.74 & 0.76 \\
\hline Phenylalanine & 189 & 182 & 197 & 190 & 7.67 & 0.30 & 0.35 & 0.99 \\
\hline Threonine & 212 & 197 & 220 & 187 & 9.01 & 0.92 & 0.03 & 0.36 \\
\hline Valine & 222 & 213 & 228 & 215 & 8.29 & 0.66 & 0.23 & 0.82 \\
\hline Tryptophan & 45.1 & 39.3 & 44.7 & 40.6 & 1.46 & 0.78 & $<0.01$ & 0.57 \\
\hline $\mathrm{BCAA}^{3}$ & 714 & 696 & 744 & 723 & 27.0 & 0.29 & 0.45 & 0.96 \\
\hline TEAA $^{4}$ & 1,799 & 1,721 & 1,872 & 1,736 & 70.9 & 0.54 & 0.16 & 0.68 \\
\hline Lysine, \% EAA & 13.5 & 13.1 & 13.3 & 13.0 & 0.39 & 0.34 & 0.03 & 0.96 \\
\hline Cysteine & 53.9 & 52.9 & 55.8 & 61.7 & 2.59 & 0.04 & 0.27 & 0.14 \\
\hline Glutamate & 602 & 620 & 622 & 685 & 25.8 & 0.06 & 0.07 & 0.26 \\
\hline Glycine & 220 & 200 & 224 & 195 & 6.38 & 0.95 & $<0.01$ & 0.56 \\
\hline Proline & 212 & 210 & 215 & 249 & 13.8 & 0.13 & 0.23 & 0.18 \\
\hline Serine & 206 & 195 & 211 & 192 & 8.47 & 0.93 & 0.11 & 0.66 \\
\hline Tyrosine & 150 & 148 & 161 & 140 & 9.34 & 0.88 & 0.25 & 0.35 \\
\hline TNEAA $^{5}$ & 2,186 & 2,116 & 2,260 & 2,203 & 72.3 & 0.25 & 0.36 & 0.93 \\
\hline Total AA & 3,984 & 3,838 & 4,132 & 3,939 & 105.3 & 0.37 & 0.24 & 0.86 \\
\hline
\end{tabular}

\footnotetext{
${ }^{1}$ Values are least squares means obtained from 4 ruminally cannulated cows in one Latin square.

${ }^{2} \mathrm{CP}=$ dietary crude protein level (low vs. high $\mathrm{CP}$ ); PS = source of protein (CM vs. W-DDGS); and $\mathrm{CP} \times \mathrm{PS}=$ interaction.

${ }^{3} \mathrm{BCAA}=$ branched-chain $\mathrm{AA}$ (isoleucine + leucine + valine $)$.

${ }^{4} \mathrm{TEAA}=$ total essential AA.

${ }^{5} \mathrm{TNEAA}=$ total nonessential AA.
} 
growth in vivo (Argyle and Baldwin, 1989; Chikunya et al., 1996; Carro and Miller, 1999). In the current study, we did not measure ruminal AA and peptide concentrations, but it is plausible that the greater RDP supply in cows fed the high-CP versus the low-CP diet with $\mathrm{CM}$ as the major protein source or cows fed the low-CP versus the high-CP diet with W-DDGS could have provided more preformed AA and peptides. This promoted microbial activity and, consequently, more $\mathrm{OM}$ and fiber digestion.

Feeding CM or W-DDGS as the major protein source in the current study had no effect on omasal $\mathrm{N}$ flows, which reflects the similar $\mathrm{N}$ intakes $(675$ vs. $673 \mathrm{~g} / \mathrm{d}$ ) for the 4 ruminally cannulated cows. This observation is in agreement with other studies (Brito et al., 2007; Brito et al., 2009; Chibisa et al., 2012) that have also observed that omasal $\mathrm{N}$ flow parallels $\mathrm{N}$ intake. Surprisingly, dietary CP content had no influence on omasal $\mathrm{N}$ flow, even though cows fed the higher-CP diet consumed more $\mathrm{N}(+0.56 \mathrm{~g} / \mathrm{d})$ compared with those fed the lower-CP diet. The reasons for these discrepant results are unclear, but it should be noted that omasal $\mathrm{N}$ flow was numerically greater $(+21 \mathrm{~g} / \mathrm{d})$ for cows fed the higher-CP diet. Across diets, the amount of dietary $\mathrm{N}$ (expressed as $\mathrm{g} / \mathrm{d}$ or percent of $\mathrm{N}$ intake) that was apparently digested in the rumen did not change and was negative for all diets, indicating that omasal $\mathrm{N}$ flow was greater than $\mathrm{N}$ intake. This observation has been reported in numerous other studies (Reynal et al., 2003; Colmenero and Broderick, 2006a; Chibisa et al., 2012; Chibisa and Mutsvangwa, 2013) and this can be attributed to the $\mathrm{N}$ contribution of recycled urea- $\mathrm{N}$ in the rumen (Broderick et al., 2008).

It is well-established that ruminal $\mathrm{NH}_{3}-\mathrm{N}$ availability has a major influence on microbial growth, so it is important to ensure that dietary supply of RDP is adequate to optimize microbial protein synthesis (NRC, 2001). Previous work indicated that the ruminal CP degradability of W-DDGS was higher than that of CM (53.2 vs. $47.5 \%$; Maxin et al., 2013a), so we expected that feeding either CM or W-DDGS as the major source of protein would result in differences in RDP supply; however, our results showed that the source of dietary $\mathrm{CP}$ had little effect on RDP supply, which tends to suggest that only small differences exist in ruminal $\mathrm{CP}$ degradability between CM and W-DDGS. It should be noted that discrepancies were noted among published studies in the in situ ruminal degradabilities of CM and W-DDGS. Whereas Maxin et al. (2013a) reported a CP ruminal degradability of $47.5 \%$ for CM, other studies (Mustafa et al., 1996; Piepenbrink and Schingoethe, 1998; Heendeniya et al., 2012) reported values ranging from 60 to $80 \%$. For W-DDGS, the ruminal degradability of $53.2 \%$ reported by Maxin et al. (2013a) is higher than values (41 to $49 \%$ ) that have been reported in other studies (Boila and Ingalls, 1994; Li et al., 2012; Zhang and Yu, 2012; Maxin et al., 2013a). Many factors, including a lack of standardization of the in situ techniques employed in various laboratories and the use of different batches of CM and W-DDGS that originate from different plants, are responsible for these discrepancies between studies. In the present study, it is plausible that differences in ruminal degradabilities of CM and W-DDGS were small, which could explain why RDP supply was similar between the 2 protein sources. When RDP supply was expressed as a proportion of dietary DMI, it ranged from 8.6 to $11.5 \%$. Broderick et al. (2007) indicated that a decrease in dietary RDP supply below the recommended 9.5 to $10.5 \%$ of DM (NRC, 2001) can depress microbial protein synthesis due to a deficiency in ruminal $\mathrm{NH}_{3}-\mathrm{N}$, total free $\mathrm{AA}$, and peptides. However, our results show that total microbial NAN flow at the omasal canal was not affected by the protein source, and even the low-CP diet containing CM that had a RDP content of $8.6 \%$ of DMI promoted similar levels of microbial NAN flow when compared with the other diets that contained RDP contents $\geq 9.9 \%$ of DMI. Further evidence that RDP supply did not limit microbial growth is provided by the fact that, at all sampling times (data not shown) during a 24-h feeding cycle, ruminal $\mathrm{NH}_{3}-\mathrm{N}$ concentrations were always $>5 \mathrm{mg} / \mathrm{dL}$, which has been suggested as the minimum ruminal $\mathrm{NH}_{3}-\mathrm{N}$ concentration that is required for maximum microbial protein synthesis (Satter and Slyter, 1974). Other studies (Balcells et al., 1993; Reynal and Broderick, 2005) have reported that ruminal $\mathrm{NH}_{3}-\mathrm{N}$ concentrations $\geq 11 \mathrm{mg} / \mathrm{dL}$ are required for maximize microbial protein synthesis; in the present study, it is noteworthy that mean ruminal $\mathrm{NH}_{3}-\mathrm{N}$ concentrations on all diets were always $\geq 11.4 \mathrm{mg} / \mathrm{dL}$, so it unlikely that ruminal $\mathrm{N}$ supply was limiting. In agreement with the present study, Chibisa et al. (2012) did not observe differences in microbial NAN supply when W-DDGS replaced CM in dairy cow diets. Across dietary treatments, 64 to $72 \%$ of total NAN flow at the omasal canal was of microbial origin, confirming the importance of microbial NAN as a source of EAA for high-producing dairy cows. The extent of the contribution of microbial NAN to omasal NAN flow reported in the present study is in close agreement with data obtained by other workers in dairy cows (69 to $74 \%$, Colmenero and Broderick, 2006a; 67 to $79 \%$, Brito et al., 2007; 71 to $76 \%$, Chibisa et al., 2012).

In a recent comparison of the AA profiles of $\mathrm{CM}$ and W-DDGS, Maxin et al. (2013a) reported that the most noticeable difference was that CM was a particularly rich source of lysine when compared with W-DDGS (4.88 vs. $2.53 \%$ of $\mathrm{CP}$ ). Also, CM had slightly greater 
concentrations of methionine (2.32 vs. $2.10 \%$ of $\mathrm{CP}$ ) and histidine (2.54 vs. $2.21 \%$ of CP) when compared with W-DDGS (Maxin et al., 2013a). After $16 \mathrm{~h}$ of ruminal incubation, these differences in AA concentrations between $\mathrm{CM}$ and W-DDGS were maintained in the RUP fraction (Maxin et al., 2013a). In the present study, omasal flows of lysine and histidine tended to be greater in cows fed CM compared with those fed W-DDGS. Because DMI and RUP flow at the omasal canal were similar between $\mathrm{CM}$ and W-DDGS, the observed differences in the omasal flows of lysine and histidine are reflective of the differences in AA composition between CM and W-DDGS. Omasal outflows of methionine were not influenced by protein source, presumably because the difference in methionine content between CM and W-DDGS was smaller than that of lysine and histidine. Together with methionine, lysine is a co-limiting AA for milk and milk protein production on a wide variety of diets that are typically fed to dairy cows in North America (Schwab et al., 1992), so our results showed that the major challenge when feeding W-DDGS as a substitute for CM is ensuring a sufficient amount of lysine supply at the small intestine. Across dietary treatments, the omasal flows of lysine were similar for diets containing CM or W-DDGS as the major source of protein, even though W-DDGS has been reported to be a poorer source of lysine when compared with CM (Maxin et al., 2013a). We can surmise that lysine supply at the small intestine was adequate on both diets.

\section{CONCLUSIONS}

Results from the present study indicate that when dairy cow diets are formulated to contain 15 or $17 \%$ $\mathrm{CP}, \mathrm{CM}$ or W-DDGS can be used as the major source of protein at dietary levels of 11 to $16 \%$ without detrimental effects on DMI and milk yield and composition. The dietary inclusion of CM or W-DDGS supported similar levels of microbial NAN flow at the omasal canal; however, feeding CM as the major source of protein elevated omasal flow of lysine and histidine, and this might be beneficial under certain feeding conditions when these EAA might be limiting for milk production.

\section{ACKNOWLEDGMENTS}

The authors thank Marlene Fehr and staff of the Greenbrae Dairy Research Facility, University of Saskatchewan, for animal care and excellent technical assistance. This research was supported by the Canola Council of Canada (Winnipeg, MB, Canada) and Agriculture and Agri-Food Canada (Ottawa, ON, Canada).

\section{REFERENCES}

Abdelqader, M. M., and M. Oba. 2012. Lactation performance of dairy cows fed increasing concentrations of wheat dried distillers grains with solubles. J. Dairy Sci. 95:3894-3904.

Allen, M. S. 2000. Effects of diet on short-term regulation of feed intake by lactating dairy cattle. J. Dairy Sci. 83:1598-1624.

AOAC. 1990. Official Methods of Analysis. 15th ed. Assoc. Off. Anal. Chem., Arlington, VA.

AOAC International. 1995. Official Methods of Analysis. 16th ed. AOAC International, Arlington, VA.

Argyle, J. L., and R. L. Baldwin. 1989. Effects of amino acids and peptides on rumen microbial growth yields. J. Dairy Sci. 72:20172027.

Balcells, J., J. A. Guada, C. Castrillo, and J. Gasa. 1993. Rumen digestion and urinary excretion of purine derivatives in response to urea supplementation of sodium-treated straw fed to sheep. Br. J. Nutr. 69:721-732.

Boila, R. J., and J. R. Ingalls. 1994. The post-ruminal digestion of dry matter, nitrogen and amino acids in wheat-based distillers dried grains and canola meal. Anim. Feed Sci. Technol. 49:173-188.

Brito, A. F., and G. A. Broderick. 2007. Effects of different protein supplements on milk production and nutrient utilization in lactating dairy cows. J. Dairy Sci. 90:1816-1827.

Brito, A. F., G. A. Broderick, and S. M. Reynal. 2007. Effects of different protein supplements on omasal nutrient flow and microbial protein synthesis in lactating dairy cows. J. Dairy Sci. 90:18281841.

Brito, A. F., G. F. Tremblay, H. Lapierre, A. Bertrand, Y. Castonguay, G. Bélanger, R. Michaud, C. Benchaar, D. R. Ouellet, and R. Berthiaume. 2009. Alfalfa cut at sundown and harvested as baleage increases bacterial protein synthesis in late-lactation dairy cows. J. Dairy Sci. 92:1092-1107.

Broderick, G. A., A. F. Brito, and J. J. Olmos Colmonero. 2007. Effects of feeding formate-treated alfalfa silage or red clover silage on the production of lactating dairy cows. J. Dairy Sci. 90:1378-1391.

Broderick, G. A., A. P. Faciola, and L. E. Armentano. 2015. Replacing dietary soybean meal with canola meal improves production and efficiency of lactating dairy cows. J. Dairy Sci. 98:5672-5687.

Broderick, G. A., and J. H. Kang. 1980. Automated simultaneous determination of ammonia and total amino acids in ruminal fluid and in vitro media. J. Dairy Sci. 63:64-75.

Broderick, G. A., N. D. Luchini, S. M. Reynal, G. A. Varga, and V. A. Ishler. 2008. Effect on production of replacing dietary starch with sucrose in lactating dairy cows. J. Dairy Sci. 91:4801-4810.

Cabrita, A. R. J., R. J. Dewhurst, D. S. Melo, J. M. Mororby, and A. J. M. Fonseca. 2011. Effects of dietary protein concentration and balance of absorbable amino acids on productive responses of dairy cows fed corn silage-based diets. J. Dairy Sci. 94:4647-4656.

Canadian Council on Animal Care. 1993. Guide to the Care and Use of Experimental Animals. Vol. 1. CCAC, Ottawa, Ontario, Canada.

Carro, M. D., and E. L. Miller. 1999. Effect of supplementing a fibre basal diet with different nitrogen forms on ruminal fermentation and microbial growth in an in vitro semi-continuous culture system (RUSITEC). Br. J. Nutr. 82:149-157.

Chibisa, G. E., D. A. Christensen, and T. Mutsvangwa. 2012. Effects of replacing canola meal as the major protein source with wheat dried distillers grains with solubles on ruminal function, microbial protein synthesis, omasal flow, and milk production in cows. J. Dairy Sci. 95:824-841.

Chibisa, G. E., and T. Mutsvangwa. 2013. Effects of feeding wheat or corn-wheat dried distillers grains with solubles in low- or highcrude protein diets on ruminal function, omasal nutrient flows, urea-N recycling, and performance in cows. J. Dairy Sci. 96:65506563.

Chikunya, S., C. J. Newbold, L. Rode, X. B. Chen, and R. J. Wallace. 1996. Influence of dietary rumen-degradable protein on bacterial growth in the rumen of sheep receiving different energy sources. Anim. Feed Sci. Technol. 63:333-340.

Christen, K. A., D. J. Schingoethe, K. F. Kalscheur, A. R. Hippen, K. K. Karges, and M. L. Gibson. 2010. Response of lactating dairy 
cows to high protein distillers grains or 3 other protein supplements. J. Dairy Sci. 93:2095-2104.

Colmenero, J. J., and G. A. Broderick. 2006a. Effect of dietary crude protein concentration on ruminal nitrogen metabolism in lactating dairy cows. J. Dairy Sci. 89:1694-1703.

Colmenero, J. J., and G. A. Broderick. 2006b. Effect of dietary crude protein concentration on milk production and nitrogen utilization in lactating dairy cows. J. Dairy Sci. 89:1704-1712.

Erwin, E. S., G. J. Marco, and E. M. Emery. 1961. Volatile fatty acid analysis of blood and rumen fluid by gas chromatography. J. Dairy Sci. 44:1768-1771.

Firkins, J. L., L. L. Berger, N. R. Merchen, G. C. Fahey Jr., and D. R. Nelson. 1986. Effects of feed intake and protein degradability on ruminal characteristics and site of digestion in steers. J. Dairy Sci. 69:2111-2123.

France, J., and R. C. Siddons. 1986. Determination of digesta flow by continuous marker infusion. J. Theor. Biol. 121:105-120.

Heendeniya, R. G.. D. A. Christensen, D. D. Maenz, J. J. McKinnon, and P. Yu. 2012. Protein fractionation byproduct from canola meal for dairy cattle. J. Dairy Sci. 95:4488-4500.

Hickling, D. 2008. Maximized utilization of canola co-products in the livestock industry. Pages 3-14 in Proc. 29th Western Nutrition Conference, Edmonton, AB, Canada. University of Alberta, Edmonton, AB, Canada.

Hristov, A. N., M. Hanigan, A. Cole, R. Todd, T. A. McAllister, P. M. Ndegwa, and A. Rotz. 2011. Review: Ammonia emissions from dairy farms and beef feedlots. Can. J. Anim. Sci. 91:1-35.

Hugli, T. E., and S. Moore. 1972. Determination of the tryptophan content of proteins by ion exchange chromatography of alkaline hydrolysates. J. Biol. Chem. 247:2828-2834

Huhtanen, P., P. G. Brotz, and L. D. Satter. 1997. Omasal sampling technique for assessing fermentative digestion in the forestomach of dairy cows. J. Anim. Sci. 75:1380-1392.

Lee, C., A. N. Hristov, K. S. Heyler, T. W. Cassidy, M. Long, B. A. Corl, and S. K. R. Karnati. 2011. Effects of dietary protein concentration and coconut oil supplementation on nitrogen utilization and production in dairy cows. J. Dairy Sci. 94:5544-5557.

Li, C., J. Q. Li, W. Z. Yang, and K. A. Beauchemin. 2012. Ruminal and intestinal amino acid digestion of distiller's grain vary with grain source and milling process. Anim. Feed Sci. Technol. 175:121-130.

Martineau, R., D. R. Ouellet, and H. Lapierre. 2013. Feeding canola meal to dairy cows: A meta-analysis on lactational responses. J. Dairy Sci. 96:1701-1714.

Maxin. G., D. R. Ouellet, and H. Lapierre. 2013a. Ruminal degradability of dry matter, crude protein, and amino acids in soybean meal, canola meal, corn, and wheat dried distillers grains. J. Dairy Sci. 96:5151-5160.

Maxin, G., D. R. Ouellet, and H. Lapierre. 2013b. Effect of substitution of soybean meal by canola meal or distillers grains in dairy rations on amino acid and glucose availability. J. Dairy Sci. 96:7806-7817.
Mulrooney, C. N., D. J. Schingoethe, K. F. Kalscheur, and A. R. Hippen. 2009. Canola meal replacing distillers grains with solubles for lactating dairy cows. J. Dairy Sci. 92:5669-5676.

Mustafa, A. F., D. A. Christensen, and J. J. McKinnon. 1996. Chemical characterization and nutrient availability of high and low fiber canola meal. Can. J. Anim. Sci. 76:579-586.

NRC. 2001. Nutrient Requirements of Dairy Cows. 7th rev. ed. Natl. Acad. Sci., Washington, DC.

Newkirk, R. 2009. Canola Meal: Feed Industry Guide. 4th ed, Canadian International Grains Institute, Winnipeg, MB, Canada.

Piepenbrink, M. S., and D. J. Schingoethe. 1998. Ruminal degradation, amino acid composition, and estimated intestinal digestibilities of four protein supplements. J. Dairy Sci. 81:454-461.

Reynal, S. M., and G. A. Broderick. 2005. Effect of dietary level of rumen-degradable protein on production and nitrogen metabolism in lactating dairy cows. J. Dairy Sci. 88:4045-4064.

Reynal, S. M., G. A. Broderick, S. Ahvenjärvi, and P. Huhtanen. 2003. Effect of protein supplements of differing degradability on omasal flow of microbial and undegraded protein. J. Dairy Sci. 86:12921305 .

Reynal, S. M., G. A. Broderick, and C. Bearzi. 2005. Comparison of four markers for quantifying microbial protein flow from the rumen of lactating dairy cows. J. Dairy Sci. 88:4065-4082.

SAS Institute. 2004. SAS/STAT 9.1 User's Guide. SAS Institute Inc., Cary, NC.

Satter, L. D., and L. L. Slyter. 1974. Effect of ammonia concentration on rumen microbial protein production in vitro. Br. J. Nutr. 32:199-208.

Schwab, C. G. C. K. Bozak, and N. L. Whitehouse. 1992. Amino acid limitation and flow to the duodenum at four stages of lactation. 1. Sequence of lysine and methionine limitation. J. Dairy Sci. 75:3486-3502

Siddons, R. C., J. Paradine, D. E. Beever, and P. R. Cornell. 1985. Ytterbium acetate as a particulate-phase digesta-flow marker. Br. J. Nutr. 54:509-519.

Udén, P., P. E. Colucci, and P. J. Van Soest. 1980. Investigation of chromium, cerium and cobalt as markers in digesta: Rate of passage studies. J. Sci. Food Agric. 31:625-632.

Van Soest, P. J., J. B. Robertson, and B. A. Lewis. 1991. Methods for dietary fiber, neutral detergent fiber, and nonstarch polysaccharides in relation to animal nutrition. J. Dairy Sci. 74:3583-3597.

Vicente, F., A. Sarraseca, A. de Vega, and J. A. Guada. 2004. Performance of several $\mathrm{Cr}$ and $\mathrm{Yb}$ analytical techniques applied to samples of different biological origin (digesta or faeces). J. Sci Food Agric. 84:2035-2040.

Zhang, X., and P. Yu. 2012. Molecular basis of protein structure in combined feeds (hulless barley with bioethanol coproduct of wheat dried distillers grains with solubles) in relation to protein rumen degradation kinetics and intestinal availability in dairy cattle. J. Dairy Sci. 95:3363-3379. 